Ensler, E. (1998). The vagina monologues. New York: Villard.

Fine, M. (1994). Dis-stance and other stances: Negotiations of power inside feminist research. In A. Gitlin (Ed.), Power and method: Political activism and educational research (pp. 13-55). New York: Routledge.

Goldstein, T. (1997). Bilingual life in a multilingual high school classroom: Teaching and Learning in Cantonese and English. Canadian Modern Language Review, 53(2), 356-72.

Goldstein, T. (2000). Hong Kong, Canada: Performed ethnography for antiracist teacher education. Teaching Education Journal, 11(3), 311-26.

Goldstein, T. (2001). Hong Kong, Canada: Playwriting as critical ethnography. Qualitative Inquiry, 7(3), 279-303.

Goldstein, T. (2003). Teaching and learning in a multilingual school: Choices, risks and dilemmas. Mahwah, NJ: Lawrence Erlbaum Associates.

Heathcoate, D., \& Bolton, G. (1995). Drama for learning: Dorothy Heathcote's mantle of the expert approach to education. Portsmouth, NH: Heinemann.

Kondo, D. (1995). Bad girls: Theater, women of color, and the politics of representation. In R. Behar \& D. Gordon (Eds.), Women writing culture (pp. 49-82). Berkeley: University of California Press.

Mienczacowski, J. (1994). Theatrical and theoretical experimentation in ethnography. ND DRAMA, Journal of National Drama, UK, 2(2), 16-23.

Mienczacowski, J. (1995). Reading and writing research: Ethnographic theatre. ND DRAMA, Journal of National Drama, UK, 3(3), 8-12.

Mienczacowski, J. (1996). An ethnographic act: The construction of consensual theatre. In C. Ellis \& A. P. Bochner (Eds.), Composing ethnography: Alternative forms of qualitative writing (pp. 244-64). New York: Altamira Press.

Mienczacowski, J. (1997). Theatre of change. Research in Drama Education, $2(2), 159-71$.

O'Connor, P. (2000). Rethinking race relations: New learnings for judges, priests and journalists. In J. O'Toole \& M. Lepp (Eds.), Drama for life: Stories of adult learning and empowerment (pp. 235-43). Brisbane: Playlab Press.

Olson, R. A. (1999). White privilege in schools. In E. Lee, D. Menkart, \& M. Okazawa-Rey (Eds.), Beyond beroes and holidays: A practical guide to K-12 anti-racist, multicultural education and staff development (pp. 834). Washington, DC: Network of Educators on the Americas.

O'Neill, C., \& Lambert, A. (1982). Drama structures: A practical handbook for beginners. London: Hutchinson.

Pon, G., Goldstein, T., \& Schecter, S. (2003). Interrupted by silences: The contemporary education of Hong Kong-born Chinese-Canadian adolescents. In R. Bayley \& S. Schecter (Eds.), Language socialization and bi-multilingual societies (pp. 114-27). New York: Multilingual Matters.

Taylor, P. (2000). The drama classroom: Action, reflection, transformation. New York: Routledge/Falmer Press.

\section{Critical moments in a TESOL praxicum}

Alastair Pennycook

\section{Departures}

The two-level suburban train clanks out of Central Station. Heading away from the city, it's not as crowded as the incoming trains, but I still find myself having to stand by the doors. We creak and rattle across several sets of points before finding our suburban heading, passing through increasingly unfamiliar station names. Outside, it's an achingly clear blue morning; the air is chilly, but the sun is starting to warm the day. It's June, which means the start of winter and the end of the semester just round the corner. Essay marking and clear blue skies. And that end-of-semester exhaustion. It's been another long semester: conferences in Manila, Vancouver, Singapore, Abu Dhabi; I was teaching from 7 to 9 last night; and here I am on a Friday morning, heading off to find a small language school somewhere in the suburbs whose address I fortunately remembered to print off from my e-mail late last night.

The TESOL (teaching English to speakers of other languages) practicum. For many of us involved in teacher education, the teaching practicum holds, I think, a certain ambivalence: It's hard work; it's disruptive; it involves lots of traveling; it's too time consuming; it demands that we show expertise in a domain from which we are often increasingly distanced in our current work. And yet, it's also a welcome break from offices, meetings, seminars, corridors; it takes us back to the classrooms where, in moments of unlikely nostalgia, we often seem to place our happiest and most successful teaching moments; it gives us a chance to engage directly with the "real work" of teaching (the classroom, the "chalkface," the "real world" - all those metaphors that construct both us and the classroom in ways we may want to both acknowledge and avoid), a chance to forget the books, the theories, the papers, the articles, the paradigms, the concepts, the need to keep up. It gives us the chance to get back to something that, at least for those of us who've taught English for many years, we may feel we really know how to do: A dozen or so years of practice and knowledge written onto our teacherly bodies. 
The train pauses at another station and I gaze out, trying to remember when I've been through this part of the city before. Nearly all the people on the platform look Southeast Asian. Vietnamese? Chinese? Korean? I find myself trying to catch what people are speaking as they get on the train. Cantonese. Then Vietnamese, I think. Not sure about the next two. Vietnamese again. Another of those complexly mixed suburbs whose daily linguistic and cultural negotiations remain largely a mystery to most of us from mainstream Anglo life. I make a mental note that this looks like an interesting area to come back and explore. But I suspect I won't be back out this way for a while. And I start to wonder about this way of looking at suburbs and the possibility of interesting restaurants and shops. What kind of center-periphery/center-suburbs relationship is this, with its fascination with the suburban high-street display of ethnic difference? The train pulls out of the station and I glance up at the route map above the door. Three more stations to go.

I'm traveling light - a briefcase with some papers for a midday meeting elsewhere slung over my shoulder - but at the same time, as with all journeys, there's a lot of other baggage with me too. The notion of embodied teacher knowledge also makes me feel uncomfortable: I'm not very sure about how my embodied knowledge of teaching relates to the curriculum the students have been following. Embodied knowledge may have an element of conservativism about it. And I haven't been teaching any of the subjects that the students take as part of the foundation for this teaching, the practicum subject itself, or the courses on curriculum design and methodology and language in social context that go with it. Indeed, rather guiltily I realize that I don't really know what's taught in those courses. Do I really know what I'm supposed to be looking for? Will I start to question precisely what this learner teacher has just been taught to do? I recall a practicum observation from last year when I a'sked the teacher why she didn't make use of the students' languages in the class. She was puzzled. Weren't we supposed to be using only English? But then again, we don't promote an English-only ideology (see Auerbach, 1993) in our courses either, so it's not exactly clear what the relationship is between the curriculum, the practice of each teacher, and the knowledge brought by the observer. ${ }^{1}$

Two more stations to go. In addition to the bag hanging over one shoulder, full of concerns about my own knowledge relative to what this teacher will know and want to know, there is a heavy bag over my other shoulder weighted down with concerns about how I will be able to introduce a critical element into this process. My aim is also to be a bit disruptive. I've been thinking and writing a lot recently about how we can understand the various meanings of the notion "critical" (see Pennycook, 2001), and I run over these ideas as we approach my destination. There's the sense of critical used in critical thinking. Unfortunately, this is both the weakest and most common version of the critical in many domains of education. This view of being critical sees the issue as only one of rational questioning procedures, as a way of trying to create objective distance, of identifying bias or lack of logic. This is all very well as far as it goes, but it is what I would call liberal ostrichism in that it buries its head in the sands of objectivism (ostrichism) and fails to link its questioning to a broader social agenda (and by so doing, of course, reproduces its own rational and liberal social agendas). Another sense of critical is concerned mainly with making things socially relevant: a reaction to the abstract objectivism (cf. Vološinov, 1973) of many domains of applied linguistics. Such a view is more promising, but without a larger vision of social critique, it remains only a version of the critical that attempts to correlate language with social context.

One more station to go. We pass through an area of brick warehouses and low factories, the drab industrial structures of a passing era. A third approach to being critical is to incorporate explicit social critique and to see one's work as overtly aimed toward trying to change inequitable social conditions and people's understanding of them. This is what I term emancipatory modernism. Its strengths are its clearly articulated social critique and explicit agenda for change; its weaknesses are its static assumptions about social and political relations and its belief in awareness of inequality as a step toward rationalist emancipation. It is this version of critical work that has come to dominate critical work in TESOL and applied linguistics, as found in critical discourse analysis (for example, Fairclough, 1995; Wodak, 1996), critical pedagogy (Giroux, 1988; Kanpol, 1994), critical literacy (Clark and Ivanič, 1997), or critical views on language policy (Phillipson, 1992). While crucially putting questions of power, inequality, rights, and injustice to the fore, this focus tends also to reaffirm concepts such as emancipation, awareness, rationality, objectivity, equality, democracy, and transformation, which, from another perspective, may be viewed as products of the same system that gives rise to those very problems that this framework aims to critique. Thus, it both critiques and reproduces at the same time.

The train pulls into the station and I walk down the platform toward the exit sign. It is this dilemma that has given rise to the postmodern, postcolonial, or post-Occidentalist (see Mignolo, 2000) concern that we need not only a critical domain of investigation but also a reappraisal of the frames of knowledge that are applied to those domains. A final way of viewing the notion of critical, then, is as a form of problematizing practice (see Dean, 1994; Pennycook, 2001), a perspective that insists on casting far more doubt on the categories we employ to understand the social world and on assumptions about awareness, rationality, emancipation, and so forth. This position has its weaknesses: in particular, its sometimes obfuscator riews on language, discourse, subjectivity, and difference, 
and its difficulty, because of its constant self-questioning and the resultant pull toward the vortex of relativity, in establishing firm enough ground to be able to articulate any clear political stance. But its strengths are also significant. As Foucault (1980) put it, "the problem is not so much one of defining a political 'position' (which is to choose from a pre-existing set of possibilities) but to imagine and to bring into being new schemas of politicisation" (p. 190). From this perspective, it is then possible to embark on the ethical task not only of seeking to understand different forms of politics but also of provincializing those European frames of knowledge that have come to dominate what counts as the critical (see Chakrabarty, 2000). At the very least, viewing the critical in terms of problematizing practice gives us a way of working in language education that doesn't reduce critical work either to the domain of critical thinking or to crude dialectics between micro and macro relations and, at the same time, keeps questions of language, discourse, power, and identity to the fore.

As I climb the stairs toward the bridge over the tracks, I start to feel weighed down by all this baggage. Hadn't I been told that all I had to do was watch the learner teacher give her lesson, discuss any particular concerns, and give her some comments as a basis for writing in her reflective journal? And yet, there's another sense of the notion critical that seems important here, too: critical as in a critical moment, a point of significance, an instant when things change. It seems to me that in the practicum observation, and, come to think of it, our teaching more generally, this is what we're looking for - those critical moments when we seize the chance to do something different, when we realize that some new understanding is coming about. This is perhaps a rather neglected notion in general approaches to teaching, discussions of teacher education, and critical approaches to education. It is perhaps inevitable that we tend to look at education in terms of the syllabus (the readings, the course materials) and the curriculum more broadly (the teaching methodology, the assignments, the discussions, the activities). But how do we capture those critical moments where something changes, where someone "gets it," where someone throws out a comment that shifts the discourse? A tough question for all teachers is how we manage to pick up on those moments of potential transformation and turn them into critical moments in both senses. And given the limited input $I$ have to this part of the teacher education program, it is this sense of the critical that will, indeed, be critical here.

\section{Destinations}

Next to the station, I cut down a small back street to the main road. I'm trying to figure out the area. Certainly Chinese and Korean, but also some Eastern European. There's a bustle of different local businesses that suggests this suburb is doing well enough. Once across the busy main road, I head past a mixed variety of shops until I find the solid dark brick of the church. It stands close to the road, a large imposing structure surrounded by a low wall. Quite strikingly, it is surrounded by notices. One announces in English and Korean its Presbyterian orientation and the times of the services; another asks in English, "What good is it to gain the whole world and lose your soul? (Mark 8: 36)"; three more announce the presence of the English Language School, one claiming, "We can help you speak better English - ENROL NOW," another "Improve your listening, speaking, reading and pronunciation skills." Classes are on Monday, Wednesday and Friday, 9:30-12:30, with "Child care available" ("Women only" has been whited out), or Tuesday and Thursday, 7:00-9:00 P.M. for "Men and women." I start trying to recreate the history behind that white-out and the relationships between these layerings of signs. Part of one of the signs has been covered by a poster - a sign of important local concerns - urging people "It's time to have your say! ON BROTHELS ... Brothels will affect you, your children, your life...." But the sign I linger over longest, in English and Chinese, announces:

Easy English Church

For New English Speakers

Sundays 9:00 a.m.-9:45 a.m.

Come and join us-Everyone welcome

I'm intrigued by this idea of an "easy English church" and the long history of connections between churches and language teaching. Following Mignolo (2000), we can crudely describe four principal phases of globalization: the Christian mission to convert the world, the European mission to civilize the world, the wealthy nations' mission to develop the world, and the transnational mission to capitalize the world. According to Mignolo, these did not replace each other, but rather can be understood in terms of "the coexistence of successive global designs that are part of the imaginary of the modern/colonial world system" (p. 280). The missionary relationship to different languages has been a complex one and certainly has not been predominantly concerned with promoting European languages. The crucial issue was always getting the knowledge of the Bible to the heathen (along with various other Christian concepts of discipline, order, cleanliness, and decency), and the best way to do that was usually by describing and then translating into local languages. Indeed, the contemporary descendants of missionary zeal may be descriptive linguists rather than English-promoting capitalists. But as global relations shifted through the second, third, and fourth phases, the relationship to European languages, and especially English, shifted. Now English had becom ? marketable commodity, with Christianity riding 
on its back. From the waves of born-again teachers from the American Midwest heading off to China and the former Soviet Union as English teacher-missionaries, to the Bible-clutching Seventh Day Adventists offering free English lessons at the corner of Hyde Park in Sydney, English has become the hook (see Pennycook and Coutand-Marin, in press). Easy English Church for New English Speakers. I make a note to find out more about the connections here between English, Presbyterianism, Korea, and China. But I've got enough baggage with me already and I'm almost late, so I hurry round the back of the church to the church hall.

This is old-style community English as a second language (ESL), a long way from the brave new world of whiteboards, colored marker pens, and plastic chairs with fold-down desks. Upstairs in the hall there's a large main room with a couple of tables covered with assorted chipped teacups and chairs gathered in a circle. Leading off from the main room with its worn floorboards, threadbare carpet, high wooden ceiling and tall church windows, there are several smaller rooms that also serve as classrooms. A brief wave of nostalgia comes over me. It's been a while since I was in a place like this, and it reminds me of some of my first teaching jobs twenty years ago. I find Liz, the student teacher, and her cooperating teacher, Barbara, and start talking about the upcoming lesson. How will Liz's lesson today fit into the broader program? What level are the students? What kind of backgrounds? What will the main focus be today? Why? Soon, the students start arriving, so I settle myself in a corner to observe. It's a small class - about ten students - at a lower intermediate level. The majority are under twenty and Korean - apparently, a number of them have come from Korea to stay with relatives here and learn English. Some connection through the church.

The teacher has chosen to do a lesson focusing on practical language for what to do when something is broken at home: vocabulary for describing various problems (my sink is blocked, the fuse has blown, etc.); practice dialogues for talking to plumbers, electricians, and so forth; and ways of asking a landlord/lady to get something fixed for you. There's a good mix of activities: a bit of grammar, plenty of vocabulary, practicing dialogues, doing free dialogues, some reading. The blackboard is used well, there are pictures to elicit and explain vocabulary items, and there's a tape for a short listening activity. It's going to be followed up by a writing task in which they will write a letter requesting for various items to be fixed. The students participate fairly actively: There's clearly quite a variety of levels in this class, but they all seem to find something useful. The main difficulty is a student of Italian background who wants to talk and to keep the teacher's attention. It's fun for a while - he's amusing and very active - but soon it becomes too much - his English is hard to follow and the others tune out when he's talking; he tends to go off on tangents and keeps demanding the teacher's attention. But how to stop him? I make a note - clearly this is something to talk about afterward. But what else? What else can I find that could be deemed critical?

\section{Connections}

Afterward, we find a quiet space in another of the small rooms off the central hall and sit down to discuss the lesson. The general process here is for the observer to give the teacher-learner a copy of the notes written during the class and to discuss various points. For the student, one goal is to pick up on a particular point of interest and to write up reflections on that point in the reflective journal, which will later be handed in to the teacher supervising the practicum. This focus on reflection fits closely with current thinking on teacher education. Summarizing recent trends, Freeman and Johnson (1998) point out several emergent reconceptualizations of teacher education in TESOL. Most significant is the recognition that "much of what teachers know about teaching comes from their memories as students, as language learners, and as students of language teaching" (p. 401). Thus, we have to take into account our students' embodied histories of learning and teaching, the memories, pains, and desires that have been written onto their educated bodies. Learning to teach is not just about learning a body of knowledge and techniques; it is also about learning to work in a complex sociopolitical and cultural political space (see Liston \& Zeichner, 1991; Pennycook, 2000) and negotiating ways of doing this with our past histories, fears, and desires; our own knowledges and cultures; our students' wishes and preferences; and the institutional constraints and collaborations.

In addition to this broader literature on teacher education, a number of educators have also addressed the teaching practicum in TESOL (Freeman, 1990; Johnson, 1996; Richards \& Crookes, 1988). The central focus of this work has been on questions such as how teachers cope with the real world of the classroom or how they start to change and learn to be more independent. Johnson (1996), for example, discusses the mismatch between a student teacher's vision of what teaching should be and her discovery of the realities of high school classrooms. Johnson concludes that preservice teacher education needs to move away from its prepackaged bits of knowledge delivered in a series of courses and instead provide preservice teachers "with realistic expectations about what the practicum teaching experience will be like and what they can expect to gain from it" (p. 48). Others, such as Gebhard (1990), have focused more on the processes of change during the practicum and, in particular, how interactions between participants can be arranged "so that student teachers have opportunities to change their teaching behavior" (p. 129). 
My own interest, however, is in how, as educators, we can intervene in the process of the practicum observation in order to bring about potential change. In addition, as already discussed, this concern is constrained by the requirement that such intervention be critical (as defined above) and by the need to work through critical moments. If such interests seem obscure and oddly constrained, I would also suggest (as I have tried to illustrate above) that they emerge from the practical concern from my own context of fitting a practicum observation into an overfull schedule (which is probably not so uncommon) and from a more general interest in how we can seize critical moments. Looking at the process of intervening in the practicum, Freeman (1990) discusses various modes of intervention: the directive - where the purpose is to "improve the student teacher's performance according to the educator's criteria" (p. 108); the alternatives option, in which the aim is to "develop the student teacher's awareness of the choices involved in deciding what and how to teach, and, more importantly, to develop the ability to establish and articulate the criteria that inform those decisions" (p. 109); and, finally, the nondirective option, the purpose of which is to "provide the student teacher with a forum to clarify perceptions of what he or she is doing in teaching and for the educator to fully understand, although not necessarily to accept or agree with, those perceptions" (p. 112).

All of this is well and good as far as it goes. My own conception of finding critical moments fits in with this broad orientation. On the one hand, like Johnson (1996), I do not believe that the teacher practicum should be viewed as a period in which teacher-learners practice the techniques they have learned in their university courses; rather, this is a time for teacher-learners to try to reconcile three competing domains: the knowledge and ideas gained through their formal study; the history, beliefs, and embodied practices they bring with them; and the constraints and possibilities presented by the particular teaching context. For this reason, it is in some ways quite useful that, as an occasional practicum observer, I do not come to the teaching practicum with a checklist of things I want to ensure are being done, though it might also be argued that if practicum observation is no more than setting one set of teacher values and beliefs (my own) against another's (the teacher-learner), we are only dealing here with a clash of potentially incommensurable teacher histories. On the other hand, my approach to teacher education is oriented toward change. For Freeman (1990), the goal of the educator is "to help the student teacher move towards an understanding of effective teaching and independence in teaching" (pp. 116-17). I would describe my own goals, however, more in terms of helping teachers to develop a critical practice in their teaching or "that continuous reflexive integration of thought, desire and action sometimes referred to as 'praxis" (Simon, 1992 , p. 49). Indeed, it might be useful to talk not only of critical praxis but also of the praxicum. This might help us think not so much in terms of the practicum, in which teacher-learners get to practice what they have learned in their theory courses, but rather in terms of the praxicum, in which teacher-learners develop the continuous reflexive integration of thought, desire, and action.

The question, then, is how to open up a critical agenda through the pursuit of critical moments. Critical approaches to language education, particularly critical pedagogy, have been critiqued for their bombastic posturing, for creating their own regime of truth, and for developing forms of language and knowledge that do not seem helpful for teachers (see Gore, 1993; Johnston, 1999). At the same time, mainstream approaches to teacher education in TESOL have frequently lacked a social or political dimension that helps locate English and English language teaching within the complex social, cultural, economic, and political environments in which it occurs (Auerbach, 1995; Canagarajah, 1999; Pennycook, 2000). What I'm looking for here, then, is a way of doing critical teacher education that does not put all its eggs in a critical syllabus basket (a critical-directive option) but rather seeks ways of probing, discussing, and negotiating in these moments of teacher reflection. Of course, ideally, the critical education curriculum might work along lines such as those described in Brutt-Griffler and Samimy's (1999) account of a critical teacher education program that used reflective diaries over an extended period to explore the construction of the native-nonnative speaker divide. But my interest here is in the smaller, unplanned micromoments when possibilities for critical reflection come and go. Rather than a critical-directive framework in which the ideas and issues have been laid out beforehand, then, I am looking for a critical alternatives or a critical nondirective option, one in which other possibilities come to the fore as we discuss choices that were made in the class. This is a search to find alternatives to the orthopraxy of the standard practicum and instead to develop a notion of critical heteropraxy within a reconceptualized teacher praxicum. ${ }^{2}$

Two other recent practicum observations have provided small examples of this. In the first, I was talking to two teachers, Sarah, whose first language was English, and Christian, for whom English was a second/third language, after their cotaught class. We got onto the topic of grammar and knowledge of language and out of this discussion emerged a shift of power. Whereas the so-called nonnative speaker of English (for a critique and discussion of this concept, see, for example, Brutt-Griffler $\&$ Samimy, 1999; Singh, 1998), Christian, had, until then, always been the disadvantaged one of these two teachers - worried about his command of English, deferring to Sarah's judgments, overpreparing materials to compensate for this presumed deficiency - as we talked our way through this, the tide star to turn: Christian was proficient in at least one other 
language; he had been an extremely successful learner of English; he had traveled, learned languages, engaged with other cultures; and he had, at his fingertips, a broad and formal knowledge of the language and how it worked. As we talked, Sarah, as a monolingual Anglo-teacher, started to become aware of her monolingualism and monoculturalism as well as the fact that it was she who was more out of place in the multilingual, multicultural context of the ESL classroom, not her "nonnative speaker" coteacher. This shift in power and moment for reflection, then, came from a small opening in the feedback session after class.

Soon after this, I was observing Bob, a teacher in a lower intermediate reading class. The text was "Charlie Two Shoes," a simplified newspaper article telling the story of a young Chinese boy who had been exchanging fresh eggs for canned food with U.S. soldiers in Southern China in 1948. Eventually, after establishing a close relationship with them and having been given the name Charlie Two Shoes as the soldiers' closest approximation to his Chinese name, the boy had been left behind when the army pulled out. In the 1980 s, one of them had received a letter from Charlie and had invited him to the United States. After various visa problems, he and his family had been granted permission to stay, and thus we see a smiling Charlie Two Shoes now living in Ohio close to his old American friends. Why this text? I wanted to know, when we discussed the lesson afterward. Well, basically, it turned out, because they hadn't done it before. But did Bob have any problems with it?

One of the first things that came up is the problem with the name. Yes, he didn't much like this idea of changing the name. He's always objected to this practice and feels Australians should learn other names. So here we started to touch on an odd disparity between Bob's own beliefs and his use of this text. I kept pushing. Why an American text? How might this text about an immigrant arriving happily in the United States relate to the lives of these students, most of whom were recent arrivals in Australia? What about the war background and the U.S. military (and the silences about what the United States was doing supporting the Guomindang in 1948)? As we talked on, the text, and its potential relationship to these students, and the silences about all of this in the reading lesson (with its nicely presented vocabulary and well-conducted discussion of grammar and meaning) became increasingly problematic. Why were we presenting stories of the happinesses of migration, with the home country only as a place to be left behind and the new country as a friendly accommodating place that will bend visa rules to secure a happy ending (around the same time a recent immigrant to Australia had burned himself to death when he had heard that his family would not be allowed to join him; more recently, Australia has developed a "Pacific Solution" in which potential immigrants are kept in camps on Pacific island and an internal policy in which new arrivals are detained for long periods in appalling conditions in detention camps)? If nothing else, after this long discussion, we walked away from this feedback session very aware that no text is ever innocent.

\section{Ruptures ${ }^{3}$}

So we start talking about the class. Liz has got a thirty-minute break between classes, Barbara can join us for the first fifteen minutes, and I have a meeting to get back to. There's never enough time. And the small wooden chairs aren't the most comfortable things to sit on. The most obvious issue was how to manage the one Italian male in the class. He wants to talk; he's happy to fill the space with hard-to-understand Italian English; he wants the teacher's attention and he's not so interested in the other students. And the other students find his English difficult to follow. They tune out and do other things when he's talking. We talk about this for a while; it's clearly the most overtly difficult aspect of the class. And, of course, both Liz and Barbara are very aware of it. They've discussed it before. Perhaps someone needs to talk to him outside the class. But are we being fair? After all, he's an active and motivated student, behaving in what may be a culturally appropriate manner for him. But there are gender politics at play here, too, and cultural appropriacy needs to be negotiated, not just accepted. And his right to behave as he wants clearly impinges on other students' rights. So as we move from a discussion of a student who talks too much to questions of gender, culture, and rights, more critical questions start to emerge. There are bigger issues here than just concerns over an individual student; questions of power have started to emerge. But we've used up almost half the time talking about this one issue. We try and come up with strategies for dealing with him, but I can't see much scope here for further critical exploration. Barbara has to go back to the class.

I take up a couple of other issues with Liz. I liked the practicality of the lesson, the clear focus on helping students to get things done. But I wonder how many people it was relevant for. The younger Korean students are living with relatives and are unlikely to have to call a plumber to get something fixed; others also didn't appear to be relating to the situation easily; few appear to be in rented accommodation where they see themselves as likely to have to deal with these sorts of situations. Though on the other hand, for one woman, parts of the class seemed to be exactly what she wanted; she asked urgent questions, checked answers, brought in other situations, wrote careful notes. To the extent that this sort of language practice may give people more possibilities to get things done and more power in interactions, this lesson certainly might be seen as critical in terms of helping to provide access to domains that are often denied. Perhaps that's enough to justify the lesson. Certainly, the class got 
some good concentrated language practice and some useful vocabulary. But we discuss ways in which she might tailor it more for the class. I don't want to be too critical here: This sort of contextually relevant language class is exactly what I'd like to see more of. How contextually relevant are we supposed to be?

I want to push the issue of the dialogues. I felt they were too cooperative. There's a long history of this problem in ESL. On the one hand, we might take this up in terms of the debate over authenticity: Should ESL classes aim to be "authentic," or should we accept them as inevitably inauthentic learning spaces? The extremes at either end of this debate seem problematic: classes that try completely to replicate the world outside might be very unproductive learning spaces, but classes that see themselves as wholly separate might be unhelpfully detached. On the other hand, we might take this up in more political terms as reflecting consensual versus conflictual views of society. From a liberal point of view, the social world is generally one in which we have common goals, and although these may at times be in conflict, and although we may need laws, regulations, and police forces to limit "antisocial behavior," civil society should generally be able to proceed as a cooperative venture. From a more critical point of view, however, society is seen as inherently conflictual, riven either by mutually exclusive class interests or by other gender, ethnic, or race divisions. From the one perspective, cooperative dialogues are the norm, and it is only antisocial or other abnormal behaviors that prevent them from happening. From the other perspective, there are no relations without power, and thus any dialogue reproduces relations of power and may be seen as ideologically normalized (see Fairclough, 1995). Given the dominance of liberal ostrichism in applied linguistics (and for a discussion of the problem that sociolinguistics has tended to operate with a liberal view of consensuality, see Williams, 1992), it is not surprising that cooperative dialogues have always been the norm. And it can therefore be argued not only that consensual dialogues are inauthentic, but also that they provide passively cooperative subject positions for language learners. ${ }^{4}$

The students were given semiscripted dialogues into which they were supposed to interject different details. The topic was calling plumbers and electricians to get things fixed. Again, nice contextual work, but I would have liked them to be more conflictual. When I call a plumber, they don't say, "Yes certainly, I'll be there at 6:00." Rather, they're busy for the next few days. They may be able to squeeze it in on Tuesday at 7:00 A.M. on the way to another job. Or, if not, they'll try to come around at lunch on Friday. Will I be home? They'll call if they can make it. Yes, they may be able to send someone today if it's a real emergency, but it'll cost extra. They don't understand what you're talking about: What did you say was broken? Perhaps you should try a builder. They don't do that sort of work. Sure they could come and have a look at it next week, but it sounds like a big job. (In fact, as I write this, I've been putting off calling a plumber for the last two weeks because blockages can be easier to deal with than plumbers.)

I suggest that for these students with their limited English skills, it'll be twice as hard. So they need tougher dialogues. A number of people have developed materials based on a more difficult world than the insipid vision of collaborative ESL texts (see Auerbach and Wallerstein, 1987; Goldstein, 1994). We talk about this possibility for a while and agree that it might be useful to try to make dialogues a bit harder, less collaborative. But I'm also a bit uncomfortable that this has been a bit critical-directive (see above discussion), that I've imposed my own agenda too much. There are some good critical possibilities here that raise questions of language, gender, power, and discrimination. But it's also not clear how relevant it is to most of these students now.

Finally, we move on to a few language points. I ask Liz what she thinks about having accepted "Close the tap" to her question about what to do when water is pouring from a tap. She's surprised. I explain that when a student offered this solution, she took it up: "Yes, you could close the tap, you could close the tap. But what if you can't close the tap?" I ask if this was a strategic move to accept this form; she says she hadn't noticed it. What did she think about having, in a sense, modeled a nonstandard form for the students? This idea worries her. Did it matter? We talk about this some more and consider different ways of understanding it. Modeling this apparently nonstandard form might be considered as (a) an inappropriate act that would have misled the students (but a reasonable knowledge of second language development suggests that we should not be too concerned about such risks), (b) an irrelevant act (we have to make our choices about what to focus on and what not to), and (c) a locally appropriate act, not just in terms of student development, but, more interestingly, in terms of what language forms will get the job done.

While turn on and turn off are considered more standard, they are also more opaque than open and close, which are widely used in many varieties of English. According to Platt, Weber, and Ho (1984),

The use of open and close for electric switches is common in many of the new Englishes, e.g., East African English, Hawaiian English, Hong Kong English, Malaysian English, Philippine English and Singapore English. It is possible to open or close lights, fans, radios and the TV. (p. 111)

And, presumably, taps. Perhaps, then, there is a reasonable argument, if not to teach these forms, at the very least to accept them. But as we push on with our discussion of this, another issue emerges. In multilingual cities like Sydney, what is the language background of the plumber likely to be? Of or -se, there's the whole issue that many communities use 
services from within that community with the result that a lot of service encounters are done in languages other than English anyway. But just as forms such as open and close are widely used in Englishes around the world, so they also develop within urban Englishes in cities such as Sydney. (I mention a sign I had seen recently in a washroom telling people not to "open the tap" in the sink.) On reflection, open and close may indeed be the best terms to teach. And we might then ask whether the students' use of the terms reflected first language influence, a guessed or generalized term, or was it perhaps a term they had already heard used? This intrigues Liz and we use up our allotted time, and a bit more, talking about the possible Englishes of Sydney.

\section{Reflections}

But it's time to go. That's it. Back to the station. Just time for a quick stand-up espresso on the way. What can we learn from this? There's quite a lot to think about on the ride back into the city (the train's fairly empty, and I get a seat). I'd like to find out more about Chinese/Korean/English Presbyterian churches. How does all this fit together? What kind of hybrid cultural mix is this? But that's for another time, another paper Having finished our talk and wished Liz well in the rest of her teaching, I reflect that we seem to have covered three critical moments: turning the discussion of the difficult student into a broader consideration of gender, culture, power, and rights; looking at how consensual dialogues not only fail to prepare students for the world outside but also potentially construct passive, consensual roles for them in the face of more powerful others; and the notion that it may not be the so-called standard versions of English that are the most common or useful for students. And out of these moments comes a further lesson for me: The first issue might be seen as critical-alternative (adapting Freeman's [1990] categorization of interventions; see above discussion) in that it provided Liz with a forum for clarifying the broader background issues involved in dealing with a difficult student; the second as critical-directive, in that I pushed my own concerns about consensuality and conflict; and the third as a critical-nondirective option in that it helped develop Liz's ability to see potential choices and to become more aware of the politics of language and standardization.

So which mattered most? Which was most critical? I have written this paper in this way in part to point to the very contingency of any answer to this question. This is also related to Canagarajah's (1996) observation that critical work that remains in standard form may reproduce as much as it resists. It is also to try to introduce more time and space and bodies into such texts. We teach and we do our teacher education in particular locations and in particular time frames. I wrote this in this manner not merely as a piece of experimental quasi-ethnography, but also to try to capture the contingencies of the moment that more standard ethnographic writing may start to sanitize. ${ }^{5}$ It is akin, in some ways, to Cynthia Nelson's (1999) attempt to describe a moment in a class she was observing in all its complexities and fleeting moments. And it is also a preliminary attempt to take up the challenge posed by Dorothy Smith's (1999) notion of "writing the social" by taking

one step back before the Cartesian shift that forgets the body. The body isn't forgotten; hence, the actual local site of the body isn't forgotten. Inquiry starts with the knower who is actually located; she is active; she is at work; she is connected up with other people in various ways; she thinks, eats, sleeps, laughs, desires, sorrows, sings, curses, loves, just here; she reads here; she watches television.... (p. 4)

I have tried here to recreate the everydayness of doing critical education and the frustration at coming up against that nagging question Am I being critical (enough)? We can write our grand abstractions about pedagogy, resistance, hidden curricula, multiliteracies, or dialogism, and we can present our examples of the ideal critical lesson, the critical curriculum, the comments from transformed students, the empowerment that came about. But it seems to me that trying to be a critical educator is more often about seeking and seizing small moments to open the door on a more critical perspective. It may be about rethinking the notion of the praxicum, but it is also about all those unplanned moments when possibilities of critical heteropraxy come and go.

Another reason for writing this is to explore a moment of practice that seems to have received little attention. How do we seek out critical moments as an ongoing process of reaction, resistance? And how do we do it on a Friday morning when we're tired? I also decided to include this interlude as an example of neither particular failure nor success. It was a good class. Liz was clearly skilled and innovative. In terms of the different ways of being critical discussed earlier, her agenda would seem to fall into the second type - social relevance. She was trying to teach socially relevant and functionally useful language items for the students. My own agenda might then be seen as trying to move from this second type to the fourth type - problematizing practice. Thus, my interest was not so much in raising "big" critical issues but in working toward a way of questioning some as yet unexplored issues with critical consequences. If we want to be able to make less opaque the practices of critical language education, we can do so by reporting on our successful critical classes or observations of successful classes. But such reporting misses the way in which seeking to be critical is an ongoing, moment-bymoment pre is of slowly prodding for possibilities. And this, of course, 
touches on one of the dilemmas of a book such as this: All those moments become packaged and frozen and start to look like solutions rather than contingent possibilities. Being a critical educator, I would suggest, has less to do with the ponderous pronouncements of emancipatory modernism and more to do with the unbearable lightness of problematizing praxis.

And so one of the lessons I have learned here is that while all three modes of intervention - critical-directive, critical-alternatives, criticalnondirective - may be successful, it may have been the latter that was the most important, at least in this instance. Our discussion afterward didn't raise any great moments of enlightenment, empowerment, or emancipation. But the significant lesson for me here was that the potential critical moment needed to emerge not only from the specific context of the class and our jointly constructed understanding of it, but also from Liz's particular interests and concerns. The point that seemed to be of most importance - at least in its potential for further consideration - did not emerge from the agenda I tried to take up, but rather from a seemingly inconsequential issue to do with language form (close the tap). It wasn't something that I would have seen as a critical issue before the class, but it emerged as a point of some significance in our discussion (this is what it seemed to me that Liz got most out of), raising questions about standards and varieties, local norms, and language use.

So the challenge was to make it critical in that moment. Underlying this question of language form is a range of issues to do with what forms we model as teachers, how and in whose interests standard varieties are constructed and maintained, what language varieties our students may need, what forms of what varieties may be used in what communities, how language forms may be related to local configurations of power, and how notions of correctness may need to be put on hold. These are small moments of critical language education, critical moments embedded in the process of discussing teaching, and these have affected both Liz's and my own thinking about apparently minor issues in English language teaching. Society hasn't been transformed. Ideological obfuscation hasn't been removed. But in many ways, this is what critical language education is all about. It's the quiet seeking out of potential moments, the results of which we don't always know. It's about the everyday. The train pulls back into Central Station, and I hurry off through the clear sun-filled streets to my midday meeting.

\section{Notes}

1. When I discussed some of this in a colloquium at the annual TESOL (Teachers of English to Speakers of Other Languages) conference in 2001 and talked about issues of pedagogical engagement, Sarah Benesch pointed out from the audience that I was lacking institutional engagement here (see Benesch, 2001 ) and that it was not enough to report thi 'strangement from parts of the pedagogical process as if these were inevitable. I take her point, though I would also reply that my point here is to ask what can still be done when the moments of engagement can be so peripheral.

2. I am using the notion of orthopraxy here in a slightly different way than Scott's (1990) conception. For Scott, the important distinction is between orthodoxy - in which we take on hegemonic beliefs - and orthopraxy - in which we act out hegemonic practices without necessarily believing them (a useful distinction, particularly in colonial contexts). I am not, however, suggesting here that orthopraxy implies the acting out of hegemonic teaching techniques without believing in their rationales (though investigating this might be a productive research project), but rather that in a context (teacher education) in which we might be seen to be teaching behaviors as well as ideas, there is a tendency toward orthopractic behaviors as well as orthodox beliefs. My main contrast, therefore, is between orthopraxy and heteropraxy.

3. The observant reader may have noticed the echoes of a well-known English as a foreign language book series in my subtitles up to this point. At a recent conference in the Philippines subtitled "Ruptures and Departures," I speculated briefly on why Departures, Connections, and Destinations were possible book titles but not a more challenging concept such as Ruptures. If anyone would like to update that series with the additional Ruptures and Reflections books, they are welcome to the titles.

4. Of course, it would be dangerous to suggest that such dialogues construct the totality of language and discourse resources of students since clearly many language learners will find resistant ways of dealing with others in conversations. Nevertheless, a good case can be made that such dialogues limit discursive possibilities for students.

5. This paper is what we might call a narrativized quasi-ethnography. Some time sequences and events have been shifted in order to make a cleaner story. Thus, although everything here is based on real events (though certain locations and names have been changed, and pseudonyms have been used), not everything happened quite in this way. For a parallel approach, see Goldstein's (2000) discussion of performed ethnography - writing plays based on ethnographic data (and see also Nelson, 2002). There are, of course, risks with this sort of approach: While I do believe that more experimental writing like this may be useful, it is also worth recalling that, as Watson-Gegeo (1988) pointed out some years ago, the field of TESOL has, for too long, been prepared to accept weak, blitzkrieg ethnographies that caricature rather than characterize. I am therefore wary of some of the problems that arise when attempting new ways to write critically.

\section{References}

Auerbach, E. (1993). Reexamining English only in the ESL classroom. TESOL Quarterly, 27(1), 9-32.

Auerbach, E. (1995). The politics of the ESL classroom: Issues of power in pedagogical choices. In J. Tollefson (Ed.), Power and inequality in language education (pp. 9-33). New York: Cambridge University Press.

Auerbach, E., \&. Wallerstein, N. (1987). ESL for action: Problem-posing at work Reading, : : Addison Wesley. 
Benesch, S. (2001). Critical English for Academic Purposes: Theory, politics, and practice. Mahwah, NJ: Lawrence Erlbaum Associates.

Brutt-Griffler, J., \& Samimy, K. (1999). Revisiting the colonial in the postcolonial: Critical praxis for nonnative English-speaking teachers in a TESOL program. TESOL Quarterly, 33(3), 413-31.

Canagarajah, A. S. (1996). From critical research practice to critical research reporting. TESOL Quarterly, 30(2), 321-31.

Canagarajah, A. S. (1999). Resisting linguistic imperialism in English teaching. Oxford: Oxford University Press.

Chakrabarty, D. (2000). Provincializing Europe: Postcolonial thought and historical difference. Princeton, NJ: Princeton University Press.

Clark, R., \& Ivanič, R. (1997). The politics of writing. London: Routledge.

Dean, M. (1994). Critical and effective histories: Foucault's methods and bistorical sociology. London: Routledge.

Fairclough, N. (1995). Critical discourse analysis. London: Longman.

Foucault, M. (1980). Power/knowledge: Selected interviews and other writings, 1972-1977. New York: Pantheon Books.

Freeman, D. (1990). Intervening in practice teaching. In J. Richards \& D. Nunan (Eds.), Second language teacher education (pp. 103-17). Cambridge, England: Cambridge University Press.

Freeman, D., \& Johnson, K. (1998). Reconceptualizing the knowledge-base of language teacher education. TESOL Quarterly, 32(3), 397-417.

Gebhard, J. (1990). Interaction in a teaching practicum. In J. Richards \& D. Nunan (Eds.), Second language teacher education (pp. 118-31). Cambridge, England: Cambridge University Press.

Giroux, H. (1988). Schooling and the struggle for public life: Critical pedagogy in the modern age. Minneapolis: University of Minnesota Press.

Goldstein, T. (1994). "We are all sisters, so we don't have to be polite": Language choice and English language training in the multilingual workplace. TESL Canada, $11(2), 30-45$.

Goldstein, T. (2000). Hong Kong, Canada: Performed ethnography for antiracist teacher education. Teaching Education, 11(3), 311-26.

Gore, J. (1993). The struggle for pedagogies: Critical and feminist discourses as regimes of truth. New York: Routledge.

Johnson, K. (1996). The vision vs. the reality: The tensions of the TESOL practicum. In D. Freeman \& J. Richards (Eds.), Teacher learning in language teaching (pp. 30-49). New York: Cambridge University Press.

Johnston, B. (1999). Putting critical pedagogy in its place: A personal account. TESOL Quarterly, 33(3), 557-65.

Kanpol, B. (1994). Critical pedagogy: An introduction. Westport, CT: Bergin \& Garvey.

Liston, D., \& Zeichner, K. (1991). Teacher education and the social conditions of schooling. New York: Routledge.

Mignolo, W. (2000). Local histories/global designs: Coloniality, subaltern knowledges, and border thinking. Princeton, NJ: Princeton University Press. Nelson, C. (1999). Sexual identities in ESL: Queer theory and classroom inquiry. TESOL Quarterly, 33(3), 371-91.

Nelson, C. (2002, April). Queer as a second language: Classroom theatre for everyone. Paper presented at the meeting of Teaching English to Speakers of Other Languages (TESOL), Salt Lake City, UT.
Pennycook, A. (2000). The social politics and the cultural politics of language classrooms. In J. K. Hall \& W. Eggington (Eds.), The sociopolitics of English language teaching (pp. 89-103). Clevedon, England: Multilingual Matters. Pennycook, A. (2001). Critical applied linguistics: A critical introduction. Mahwah, NJ: Lawrence Erlbaum Associates.

Pennycook, A. \& S. Coutand-Marin (in press). Teaching English as a missionary Language. Discourse: Studies in the Cultural Politics of Education, 24.

Phillipson, R. (1992). Linguistic imperialism. Oxford: Oxford University Press. Platt, J., Weber, H., \& Ho, M. L. (1984). The new Englishes. London: Routledge. Richards, J., \& Crookes, G. (1988). The practicum in TESOL. TESOL Quarterly, 22(1), 9-27.

Scott, J. (1990) Domination and the arts of resistance: Hidden transcripts. New Haven, CT: Yale University Press.

Simon, R. (1992). Teaching against the grain: Essays towards a pedagogy of possibility. Boston: Bergin \& Garvey.

Singh, R. (Ed.). (1998). The native speaker: Multilingual perspectives. New Delhi, India: Sage.

Smith, D. (1999). Writing the social: Critique, theory, and investigations. Toronto, Ontario, Canada: University of Toronto Press.

Vološinov, V. N. (1973). Marxism and the philosophy of language (L. Mtejka \& I. R. Titunik, Trans.). Cambridge, MA: Harvard University Press. (Original work published 1929.)

Watson-Gegeo, K. (1988). Ethnography in ESL: Defining the essentials. TESOL Quarterly, 22(4), 575-92.

Williams, G. (1992). Sociolinguistics: A sociological critique. London: Routledge.

Wodak, R. (1996). Disorders of discourse. London: Longman. 